\title{
9 Karaite Settlement in Medieval Lithuania
}

Karaites settled in medieval Lithuania - particularly in Trakai (Troki), where they established a community and began a chronicle of Karaites in the Baltic Region of Eastern Europe. The history of Karaites has already been analysed by many Jewish, Polish, Lithuanian, Russian, American, and other scholars who focused on finding historical truth by establishing some facts. ${ }^{1}$ This article examines how the history of this settlement has been passed down through written documents and oral tradition. It serves as an important reminder of the process of Karaite identity formation and draws attention to the Hebrew heritage. It addresses records from the fifteenth to the early twentieth centuries and delineates the way in which interpretations of this history have shifted over time, both among the Karaites themselves and in the work of historians who have worked with this subject. As there are some discrepancies in both the source materials and the publications - the result of inaccurate dates, locations, events, and perspectives - I have examined both Karaite and Jewish works, including those of independent researchers. A short Hebrew text regarding the settlement of Karaites in Lithuania from Mordecai Sultansky's Zecher Tzadiqim (זכר צדיקים) deserves particular attention. ${ }^{2}$ He was the first to attempt a general history of Karaites from their origin until his own time. I have also analysed the Karaite deeds published by Jacob Mann ${ }^{3}$ - found in the Firkowicz collection - which are in fact the only medieval sources that provide a window into the daily life of the Karaite community in Lithuania. Finally, this article also considers relations between two religious groups, Karaites and Rabbanites.

The earliest known Karaite sources date back to the late fifteenth century. Although they describe the medieval life of Karaites in Trakai, ${ }^{4}$ they are not

1 See, for example, Bałaban 1927; Bershadsky 1883; Gąsiorowski 2008; Kizilov 2003: 29-45; Sinani 1890; Szyszman 1933-1934: 29-36; Witkowski 2013: 211-214.

2 Mordecai ben Joseph Sultansky (1772-1862) was one of the earliest Karaite historians in Eastern Europe. He was born in Lutsk, Volhynia, where he officiated as hacham until he had a conflict with his disciple Abraham Firkowicz in 1821. He then moved to Chufut-Kale and subsequently to Yevpatoriya, both in Crimea, and later to Kherson in Ukraine. He also wrote a Hebrew grammar - Petah Tiqvah (פתח תקווה), Yevpatoriya, 1857 - and a philosophical work Sefer Metiv Da'at (ספר מטיב דעת), Yevpatoriya, 1858; see Schur 1995, 268.

3 Mann 1935. The second volume includes many Karaite documents from the Near East, Turkey, the Crimea, and Lithuania and Poland.

4 Mann claims that in the Middle Ages only Karaites had the privilege of living in Trakai. According to a letter from Joseph ben Mordecai of Trakai to Elijah Bashyatzi (1484 or 1485),

(c))BY-NC-ND (C) 2015, Klimova, published by De Gruyter.

This work is licensed under the Creative Commons Attribution-NonCommercial-NoDerivatives 3.0 License. 
related to the arrival of Karaites in Lithuania. Correspondence prior to the expulsion in 1495 confirms that the Trakai Karaite community remained in contact with the Karaite centre in Constantinople. This popular form of exchange and consultation about religious questions is primarily associated with the leading Karaite figure Elijah Bashyatzi. ${ }^{5} \mathrm{He}$ was the ideological force for Karaite rapprochement with Rabbanism 6 and the most important codifier of Karaite Law. His book 'Aderet 'Eliyahu, meaning the "Mantle of Elijah", which in fact was finished by his son-in-law Caleb Afendopolo, is the most important Karaite halachic work. ${ }^{7}$ Bashyatzi provided his expert advice regarding adopting certain rabbinic innovations. One of these letters concerns permitting Sabbath candles, which were already being used in Adrianople and Constantinople in the fifteenth century. This issue caused divisions among Karaites, as not all believers were ready to accept the change, particularly because it was a Rabbanite innovation. In a 1485 letter to Trakai, Bashyatzi expressed his support for the new custom, but Joseph ben Mordecai firmly opposed the Rabbanite adaptation of heating the stoves on cold winter Sabbaths. Nonetheless, it was only a matter of time before this practice was adopted, the freezing Lithuanian winters proving persuasive. ${ }^{8}$

In 1483, the Trakai elders wrote to the Constantinople centre for spiritual guidance. They presented a self-deprecating picture of the spiritual state of affairs among the sectaries in Lithuania: ${ }^{9}$

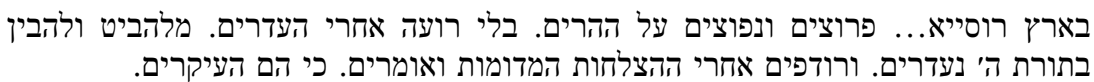

[In the land of Ruthenia (...) scattered and dispersed over the mountains without a shepherd looking after the flocks, refraining from understanding God's Torah, but pursuing imaginary successes (viz. those of mundane life) and regarding them as essential.]

Rabbanites were residing in Trakai temporarily: "והראנו לרבנים המתאכסנים פה בטרוקי יערים סוכי ועוזר הרופא מכרקוב וליתר הרבנים שהיו פה [we indicated the Rabbanites who are here in Troki as transients (were) Jacob Suchy, an assistant to a physician from Cracow, and others]", Mann 1935, 559.

5 Mann 1935, 698.

6 In contrast to Rabbanism, the mainstream of Judaism, Karaism does not recognize the Oral Law or the Talmud (Schur 1995, 222, 240).

7 It was published for the first time in Constantinople in 1531 as Sefer ha-Mitzvot ha-Niqra' 'Aderet 'Eliyahu (ספר המצוות הנקרא אדרת אליהו).

8 Mann 1935, 684.

9 The translation of this and following quotes from the correspondence between the Trakai and Constantinople communities presented here is by Mann. My changes and additions appear in italics. 
The writers express their worries and feelings while calling people evil and sinners, even children of whoredom (ילרי זְנוּנִים - - Hosea 1. 2). The early leadership had died, and the Karaite community in Trakai lacked decent successors who were able to take responsibility for providing the necessary services:

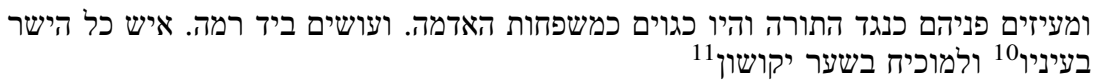

[(People) are arrogant toward the Torah, and they are like the nations of the earth families. They act high-handedly. Everyone does whatever seems right in his own eyes, and lays a snare for he who reproves inside the gate.]

It was probably the custom to begin letters in such a way, as later, to the contrary, the elders boast about their situation:

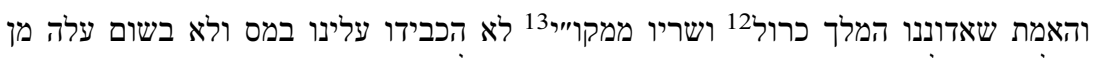
העלות ואין לנו שום מונע ומוחה בקייום בית ישראל ואיו

[The truth is that our lord the king and his officers smite through the loins of his adversaries and enemies, that they rise not again, and have not imposed upon us heavy taxes or other exactions, and nobody prevents us and keeps us from practising our religion. We have a Bet-Din with a Dayyan and Shofet to enforce the laws and judgments of Israel.]

In this letter the Trakai elders asked for a scholar from Constantinople to come to teach them "Torah and wisdom [תורה וחכמה]". They also wrote that they had heard about the Code of Law by Tobias ben Moses (from the eleventh century) and requested a copy. The letter indicates a full awareness of a truly poor spiritual condition. It alludes to some of the educational problems among the Karaite population, and it evidences a deep desire on the part of the Trakai elders to create a better future for the Karaites and to preserve their religion. ${ }^{14}$

In 1484, Elijah Bashyatzi wrote a reply, which was co-signed by other Karaite scholars. He expressed both his respect for the Trakai elders for their attention to Karaite spiritual life and his admiration for their intellectual eagerness to achieve a higher level of knowledge, skill, and competence, so as to counter arrogance in the face of Torah Law and to unite "wisdom [science] with reli-

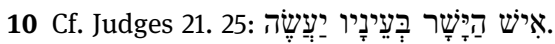

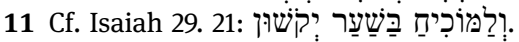

12 Polish król (king).

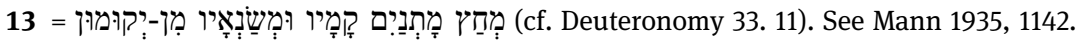

14 Mann 1935, 698-699, 1139-1143. 
gion". He says that the goal is to establish the religion of God for the entire world and its creatures to see. He stresses the perfection of the Torah:

\section{ואם אין שלימות ראשון אין שלמות אחרון כי האחד דרך והגעה. אל השני בישועה. ולכן}

שמתם מגמתכם שימות

[If there is no first perfection, then there is no final perfection. There is only one way and one approach. There is no other way to salvation, and that's why you make that your goal.]

Unfortunately, there was no Constantinople Karaite scholar able to leave his family and go to Trakai, so Bashyatzi suggested that some young people from Trakai visit Constantinople to study "the words of Torah and the words of wisdom [דברי תורה ודברי חכמה]”, and on their return share their knowledge and וירביצו תורה] experience with their countrymen and "teach the Torah of Israel בישראל]". He promised to provide a quality education, as well as accommodation and other necessities. Although the plague was widespread in Constantinople at the time, Bashyatzi assured the Trakai elders that he would protect the students, taking refuge with them in one of the villages. As for the sectaries who were reluctant to keep religious customs, Bashyatzi recommended issuing a warning. If that did not help, then they should be judged "by our Torah [ כפי [דין תורנו". As a last resort, they were to be excommunicated from the community, with their property placed under herem. Bashyatzi had to postpone sending Tobias' Sefer Mitzvot (ספר מצוות) and the commentary on the whole Bible (פירוש עשרים וארבעה של חכמינו), which there had been no mention of in previous correspondence, as the sofer needed to make a copy had yet to be located, and Bashyatzi did not want to wait any longer to send his reply. ${ }^{15}$

The origin of the first Lithuanian Karaite settlements can be traced using a later written tradition. A 1668 letter of complaint from the Lithuanian Karaites to the Rabbanites in Brest-Litovsk, found in the Firkowicz collection, reads: "for four hundred years, and even longer, our ancestors strived to expand their borders in Troki שמארבע מאות שנה ויותר טרחו קדמונינו להרחיב גבולם] בטרוקי]". ${ }^{16}$ This would suggest that the Karaites first settled in Lithuania in the thirteenth century. On the contrary, according to another document, an historical memorandum discovered by Firkowicz in an old manuscript, Karaites from Solkhat arrived in Trakai in 1399:17

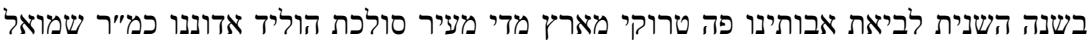

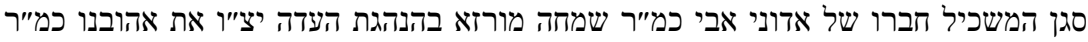

15 Mann 1935, 699-700, 1143-1148.

16 Mann 1935, 557. The transcription of the Polish name for Trakai.

17 Mann 1935, 556-58, 1178-1179. 
משה בשנת הק״ס ויגדל משה הלוך וגדל עד כי היה שר קפיטיטן בחצר אדוננו המלך כזימיר

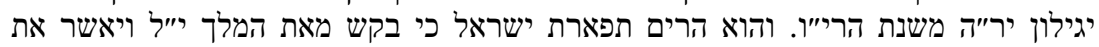

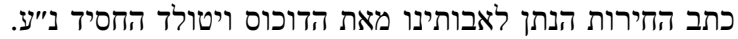

[In the second year after the arrival of our ancestors here in Troki from the land of Media ${ }^{18}$ from Solkhat ${ }^{19}$ our rabbi Samuel, who had a position (in the community), a friend of our rabbi Simcha Murza, one of the community leaders, may his Rock keep him and grant him life, begot our beloved rabbi Moses, in 1400. Moses became famous, so he was appointed as the minister, the captain in the court of our Lord, King Casimir Jagiellon, may his glory be exalted, in the year 1456. He (Moses) raised the glory of Israel, because he asked the King and he (the king) confirmed the charter of privileges, ${ }^{20}$ which was given to our forefathers by the aforementioned merciful Duke Witold ${ }^{21}$.]

In the book, Zecher Tzadiqim, by the nineteenth-century Karaite writer and hacham Mordecai Sultansky, ${ }^{22}$ the introduction to the history of the Trakai Karaites reads: ${ }^{23}$

אופן וזמן העתקת הקראים מקירים לארץ פולין.

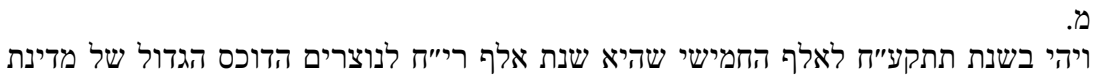

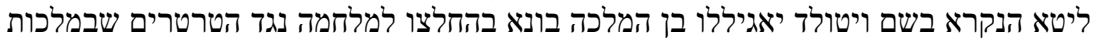

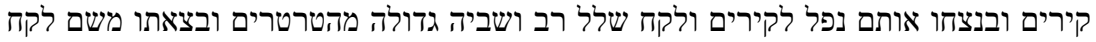

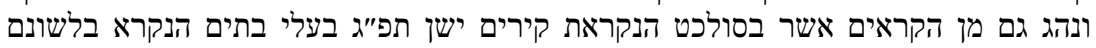

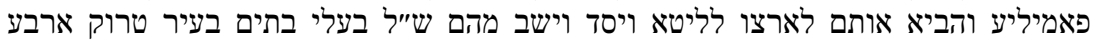

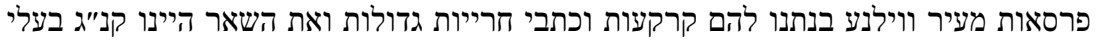
בתים הושיכם ויסדם בעיר פונעואז בהגינו וכהדריגו גם אותם באותם החריות ה....

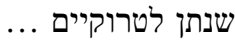

18 The land of Media corresponds to Crimea (Mann 1935, 1178).

19 Solkhat is a Turkish form of the Italian name Solcati. The present name of the town is Staryi Krym (in Ukrainian, Старий Крим).

20 The Rabbanites acknowledged that the Karaites were granted legal residence permits in Trakai even before they themselves received permits in Vilnius. In 1664, the Vilnius qahal applied to the leaders of the Lithuanian $v a^{\prime} a d$ for the right to re-establish the Karaite settlement in Trakai, which had been destroyed during the 1655 Muscovite and Cossack invasion. It is written in the request that the Karaites "long ago received the right to reside in Trakai. Several tens of their families had lived there. Their cemetery was the burial ground for many of (our) members, before our own was established. They also have charters in Trakai that we have borrowed several times. We were compelled to borrow them from there (Trakai)". See Mann 1935, 559-560.

21 The transcription of a Polish form of the name Vytautas.

22 Sultansky 1920, 107-110.

23 In the English translation, I have preserved the Polish names and the names as presented in the original Hebrew text. 
ובשנת חמשת אלפים ושש שנים ליצירת עלמא, שהיא שנת אליכ אלף רמיכ"ו למספר הנוצרים אותו

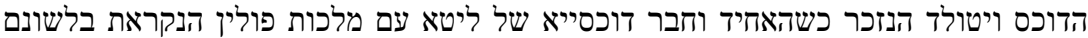

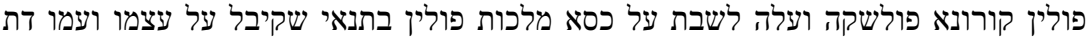

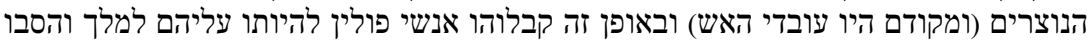

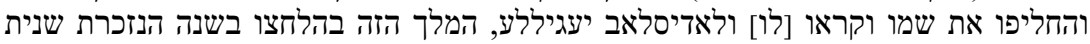

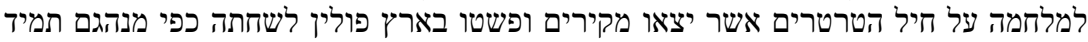

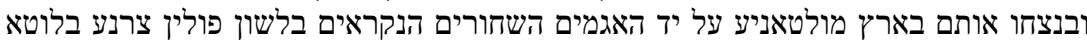

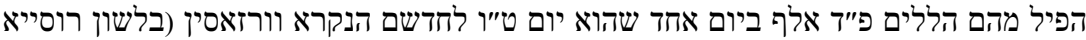

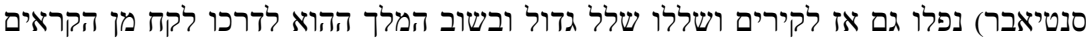

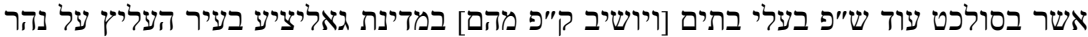

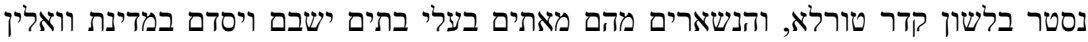

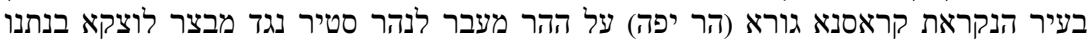

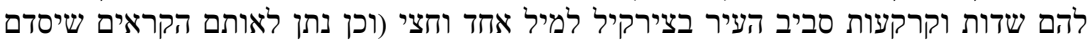

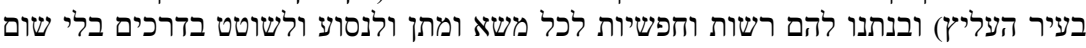

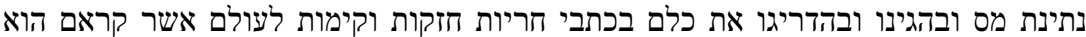

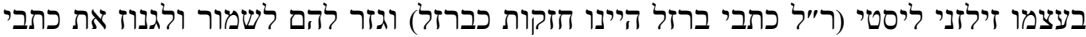

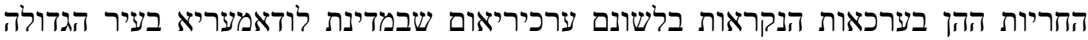

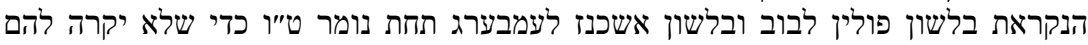

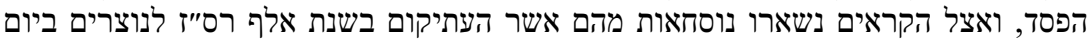

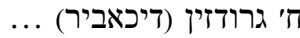

[(40) And it happened in 4978, in 1218 of the Christian era, the Grand Duke of the Duchy of Lithuania, called Witold Jagiełło, the son of Queen Bona, went to war against the Crimean Tatars in the Crimean Empire of the Khan. He defeated them, invaded Crimea and took much booty and a great number of prisoners among the Tatars. When leaving Crimea, he took and carried away the (people) among the Karaites from Solkhat, called Old Crimea - 483 Karaite homeowners; families ${ }^{24}$ in their language - and brought them to Lithuania. He settled 330 of them in the town of Troki, situated 4 parasangas ${ }^{25}$ from the city of Wilno, ${ }^{26}$ provided them with land and gave them charters of great privileges. The remaining 153 families he settled in the town (called) Poniewież, ${ }^{27}$ while protecting and giving them the same great privileges (...) as were bestowed upon the people of Troki (...)

(41) In the year 5006 from the creation of the world, which corresponds to 1246 by Christian reckoning, the same Duke Witold, who has been mentioned, united and joined the Duchy of Lithuania with the Kingdom of Poland, which is called Korona Polska ${ }^{28}$ in their Polish language. He came to the throne of the kingdom of Poland under the condition that he and his nation would accept the Christian religion (previously they were fire worshipers). In this case, the Polish people took him to be king over them, they transformed

24 The transcription of Ashkenazi.

25 An ancient Persian unit of distance, usually estimated at $5.6 \mathrm{~km}$. Four parasangas is approx. $22.4 \mathrm{~km}$.

26 The transcription of the Polish rendition of Vilnius.

27 The transcription of the Polish rendition of Panevėžys.

28 The transcription of the Polish rendition of Crown of Poland. 
and changed his name, and they called him Władysław Jagiełło. In the aforementioned year, this king went to war for the second time against the Tatar army, which came from Crimea and attacked the Polish land, destroying everything, as is their habit. After defeating them in the country of Moltwania, ${ }^{29}$ next to the Black Lakes, called Czarne Błota ${ }^{30}$ in Polish, with 84,000 of them falling on the first day, which was the fifteenth day of the month called wrzesien ${ }^{31}$ (сентябрь ${ }^{32}$ in Russian), they attacked again and captured a huge bounty. On his way home, the king also took 380 Karaite families from Solkhat with him (and settled 180 of them) in the land of Galicia, in the town of Halicz, ${ }^{33}$ near the Nester River, ${ }^{34}$ which was called Turla in the Qedar (i.e., Turkic) language. ${ }^{35}$ The rest of them - 200 families - were settled in the land of Wołyń, ${ }^{36}$ in a town called Krasna Góra (Beautiful Mountain) on the hillside across the Styr River from the Łuck $^{37}$ fortress. He gave them about one and a half miles of fields and land ringing the town (in like manner he gave it to the same Karaites who were settled in the town of Halicz), and he gave them rights and freedoms in all commercial matters and duty-free use of the roads. He arranged and approved everything in an authoritative and eternal charter of privileges, which he himself called żelazne listy ${ }^{38}$ (I want to say that the privileges were just as strong as iron), and, in order to avoid any damage to them, he ordered them to protect and preserve these privileges in the stores, called archivum in their language, which were in the land of Lodomeria, in a big town called Lwów ${ }^{39}$ in the Polish language and Lemberg in the Ashkenazi language (i.e. Yiddish) at number 15. Some versions were left among the Karaites, who copied it in the year 1267 by the Christian reckoning, on the eighth of grudzien ${ }^{40}$ (декабрь $\left.{ }^{41}\right)$.]

The Zecher Tzadiqim was published by Samuel Poznański and included his commentaries on historical truth. Poznański stressed the fact that the above story had earlier been told to Rabbi Moshe Tenenboim (משה טענענבוים) by the Karaite hacham from Halych, Josef Leonovich (יוסף ליאונוביץ). Leonovich copied it verbatim from a letter sent by his father Abraham Leonovich (יוסרהם ליאונוביץ), who himself had copied it in the Lviv archives. This version was later published in Hanesher (הנשר) 15 on 2 Nisan 5624 (1863) and in Sinani Isaac's Istoriya vozniknoveniya i razvitiya karaimizma (История возникнове-

29 Bałaban suggests that this should read Moldavia (Bałaban 1927, 11).

30 The transcription of the Polish rendition of Black Muds.

31 The transcription of the Polish word for September.

32 The transcription of the Russian word for September.

33 The transcription of the Polish rendition of Halych.

34 Bałaban suggests that it should read Dniester (Bałaban 1927, 11).

35 The language of the nomads.

36 The transcription of the Polish rendition of Volhynia.

37 The transcription of the Polish rendition of Lutsk.

38 The transcription of the Polish term for the iron letters.

39 The transcription of the Polish rendition of Lviv.

40 The transcription of the Polish word for December.

41 The transcription of the Russian word for December. 
ния и развития караимизма). Nonetheless, it does not conform to historical reality: The Grand Duke Vytautas was the ruler in 1392-1430, and Queen Bona's son was Sigismund II Augustus, King of Poland and Grand Duke of Lithuania, the last of the Jagiellonians, who lived in 1520-1572. Queen Bona's son is not mentioned in Hanesher, ${ }^{42}$ and, reasonably enough, Sinani changed the year from 1218 to $1418 .{ }^{43}$

In 1912, Józef Smoliński wrote a response to Poznański's commentaries “Jeszcze w sprawie Karaimów (Odpowiedź p. Poznańskiemu) [ More on the Karaite Question (A Reply to Mr. Poznanski)]”. In it, he stressed that the Karaites had arrived in Lithuania in the fourteenth century: 44

Znany przywilej Witolda W-go Ks. Lit., ustanawiający stosunek żydów do chrześcijan, wyd., w Łucku w 1388 roku, a ośmiu dniami wcześniej zastosowany tamże do utworzonego dekanatu karaimów w Trokach, rozszerzający i objaśniający dawniejsze nadania, o których wspomina, nie może odnosić się do żydów rabinistów, gdyż jak przyznaje p. Poznański, w pierwszych przywilejach nie odróżniano karaimów od rabinistów; w tym wypadku jednak nie można twierdzić, aby nazwano ich, jak pisze p. P., 'wszystkich pospo-

42 The published text "לקורות בעלי מקרא [Le-Qorot Ba'aley Miqra']" (no author) is as follows (Hanesher 15 [1864]: 60):

בשנת אלף רי"ח למספר הנוצרים, הדוכוס הגדול של דוכסיות ליטא וויטולד (Witold)

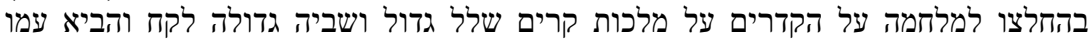

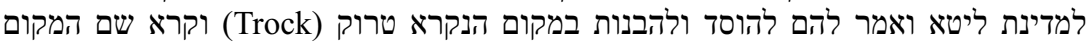

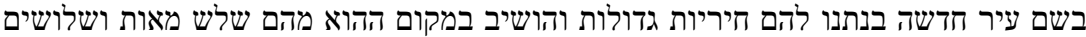

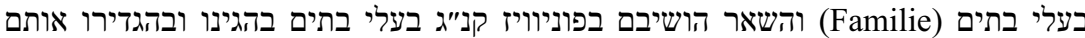
באותם החריות בעצמם, ר"ל של בעלי עיר חיר חדשה הנ"ל.

[In 1218, by the Christian reckoning, the Grand Duke of the Duchy of Lithuania, Witold, went to war against the Tatars, the Khan of Crimea. He took much booty and a great number of prisoners and brought them with him to the state of Lithuania. He told them to settle and establish a residence in a place called Troki. He called the place a new town. He gave them far-reaching privileges. He settled 330 of their families there, and the remaining 153 families were settled in Poniewież, where they were also protected and received the same far-reaching privileges as the families of the new town mentioned above.]

43 Sinani 1890, 279-281. Sinani rewrote the fragment from Sultansky with the following changes:

Въ 1418 году Витгольдъ Ягелло, великій князь литовскій ополчился [...] Въ 1426 году, тотъ же великій князь литовскій, Витгольдъ Ягелло, присоединилъ Литовское княжество [...] случилось 15-го Сентября 1426-го года

[In 1418, the Grand Duke of Duchy of Lithuania, Witold Jagiełło, went to war against (...) In 1426, the same Duke Witold Jagiełło united (...) It happened on the fifteenth of September 1426.]

44 Smoliński 1912, 353. 
lem' judei trocenses, gdyż jak to najwyraźniej widzimy z późniejszych nadań i chociażby z przytoczonego w art. moim przywileju Władysława IV, wyd. karaimom w Warszawie w 1646 r., żydzi rabiniści nie tylko nie mieli w Trokach żadnych zgoła przywilejów osadniczych, ale nawet nie mieli prawa tam zamieszkiwać. Król Władysław IV potwierdza to tylko, powołując się na dawne nadania: jak czytamy 'żydzi rabinowie czasy niedawnemi w mieście naszem trockiem mieszkania sobie wynająwszy, w onych rezydując - wolności żydom karaimskim od ś. p. przodków Naszych y Nas samych nadanych nullo iure zażywają ...' Nie będzie więc „błędnem” twierdzenie, że przywileje dawane „żydom trockim” stosują się do karaimów, i żydzi rabiniści nie mogą ich sobie przypisywać, gdyż pod żadnym względem nie byli uprzywilejowanymi mieszkańcami Trok.

[The privilege promulgated by Vytautas, the Grand Duke of Lithuania is recognized, and, it established the relationship of Jews to Christians, given in Lutsk in 1388, although eight days earlier, it had been used to set up the Karaite deanery in Trakai, expanding and clarifying older grant rights, which, as he mentions, cannot refer to Rabbanite Jews, because, as Mr. Poznański admits, no distinction between Karaites and Rabbanite Jews existed in the original privileges: In this case, however, it cannot be said that they were called, as Mr. P. writes, "all together" judei trocenses, because as we can see clearly from rights later granted, even if only the privilege of Władysław IV given to the Karaites in Warsaw in 1646, which is cited in my article, Rabbanite Jews not only did not have settlement privileges in Trakai, they did not even have the right to reside there. In confirming this, King Władysław IV simply relied on past grant rights. As we can read: "Recently in our town of Trakai, the Rabbanite Jews who were renting housing or residing there made use of the freedoms of our late ancestors among the Karaite Jews, which were given to us as nullo iure ..." That's why it is not so "wrong" to say that these privileges were granted to "Trakai Jews", to the Karaites, in fact, and Rabbanite Jews could not claim them, because they were in no way privileged inhabitants of Trakai.]

In 1927, Majer Bałaban published the Polish translation of Mordecai Sultansky's aforementioned history of Karaite settlement in Trakai in Studja Historyczne. ${ }^{45}$ He points out that three charters of privilege were granted to the Trakai Jews in 1441 by Casimir IV Jagiellon, in 1492 by Alexander, and in 1507 by Sigismund I. Although the Karaites are not specifically mentioned as the recipients of the charters, it is to them that they were granted. ${ }^{46}$ Grand Duke Casimir Jagiellon resisted the Catholic opposition to the Jews under his rule, allowing them to have their own law courts and to trade in agricultural and dairy products. In 1441, he passed the Magdeburg Law, ${ }^{47}$ which granted the Karaite community

\section{Bałaban 1927, 11.}

46 Bałaban 1927, 57.

47 According to Bershadsky, the main reason for such generosity and kindness on the part of the Grand Duke was the poverty of the Trakai Jews and some damages (damna). In order to help them cope with the extremely difficult situation they found themselves in, he granted them the same privileges as the Christian sections of Vilnius, Kaunas, and Trakai (Bershadsky 1883, 241-242). 
of Trakai equal status with the Gentile municipalities of Trakai. The Trakai Jews (Karaites) were no longer under any jurisdiction except that of a shofet (in later Polish documents, wójt ${ }^{48}$ [mayor]) who was responsible for resolving any litigation among them. ${ }^{49}$ The shofet was elected for a two- or three-year term by the representatives of an irregular assembly, but the election had to be confirmed by the governor (in Polish, wojewoda), who received a fee or 'present' for his confirmation. The shofet was responsible to the Grand Duke of Lithuania for his actions. A peasant kmieć, or nobleman, caught red handed committing a crime in the Jewish territory could only be subjected to the Jewish court system with the knowledge and agreement of wojewoda. The Trakai Jews were obliged to pay an annual rent, but were free of all impositions. To meet the needs of the Polish-Lithuanian Commonwealth, under the Magdeburg Law, they, like other cities, were obliged to make extraordinary contributions. They received half of the revenue of a weighing house and of a woskobojnia (a wax producer). When visiting Trakai in December 1492, Grand Duke Alexander exempted the Trakai Jews (Karaites) from all tolls - toll roads, toll bridges, and royal, private, clerical, and lay tolls - allowing them to travel freely and transport goods throughout the Grand Duchy of Lithuania, as was already the case for the townspeople of Vilnius and Trakai. ${ }^{50}$

According to Bałaban, the privileges gained by the Karaite community allowed them to create not just a qahal, but an entirely separate town. This resulted in Trakai being divided into two parts with a so-called border being the 'Swan Bridge' (lebiednyj most) alongside a small river. In 1485, there was a conflict between Catholic and Orthodox burgesses and the Karaites about the srebszczyzna ${ }^{51}$ tax. In response, Casimir Jagiellon asserted that the town had already long been divided into two parts, and that this division had changed nothing about the taxes and tributes to be paid. He promised to find a solution to the problem when he next visited, but that visit never occurred. In 1517, the Karaites once again appealed to Sigismund I about the same issue. On 24 April 1517, the king commanded the Trakai wojewoda to call for the town wójt Miko-

48 According to Bałaban, the first written mention of the institution of wójt dates to the early sixteenth century, following the return from expulsion and the reconfirmation of the former privileges of 1441. On 25 November 1508, the Trakai wojewoda Mikołaj Mikołajewicz told his deputy Fjedor Czaplicz that the king had given his permission to the Trakai Karaites to have a wójt, and Abraham had been chosen and confirmed for this position. The next wójt was Mordecai (1517). See Bałaban 1927, 65.

49 Bershadsky 1883, 241-242.

50 Bałaban 1927, 58.

51 The land tax imposed upon the inhabitants of Lithuania and Ruthenia in the Middle Ages: It derived its name from the fact that it had to be paid in silver. 
łaj, so that he could be instructed to maintain a strict divide between the Christian and Jewish (Karaite) sections of Trakai. The Karaites were represented by their wójt, Mordecai. ${ }^{52}$

In 1936, Abraham Szyszman, writing in the Karaite journal Myśl Karaimska (Karaite Thought), dated the first Karaite settlement in Trakai to the late fourteenth century. In 1397, Algirdas, the Grand Duke Vytautas' commander, defeated three Tatar rulers who united against him. The first was the ruler of the Crimean region (main town, Solkhat), the second, the ruler of the Kyrk Jer region (main town, Kyrk Jer, viz. Chufut-Kale), and the third, the ruler of the Mangup region (main town, Mangup Kale). Algirdas invaded the Crimean Peninsula, getting as far as Solkhat, the main Tatar centre in Crimea. In late 1397, having regained control of Tokhtamysh (in Tatar, Tuqtamış), Grand Duke Vytautas removed many Tatars, as well as 383 Karaite families, from the Solkhat area. According to Szyszman, Grand Duke Vytautas turned over some of his Tatar captives to King Jogaila, who forcibly baptized half of them. The other captives were settled on the territory of the Grand Duchy of Lithuania and were not obliged to change their religion. The Karaite territory ran from Swan Bridge to the Tatar Wall, with the Lithuanian tribal population being resettled elsewhere. As Szyszman has noted, the strategic location of the Karaite settlement in Trakai and later privileges indicate that Karaites were accepted to the knighthood of the Grand Duchy as a significant social group with land rights. He further noted that it was only in 1579 that the Karaites were exempted from the obligation to watch the castle and cultivate land in Old Trakai. 53

It is worth noting that Szyszman describes the Charter of Vytautas as the first charter of privileges. It is "probably lost forever, but the next charter was preserved. It confirmed that the Karaites were given residence in the territory of the former capital Trakai, they were not restricted to the religious beliefs, and they were fully trusted in the Grand Duchy". 54

In 1935, in his book Texts and Studies in Jewish History and Literature, Jacob Mann addresses the expulsion of Karaites in the late fifteenth century. Grand Duke of Lithuania Alexander, Casimir's fourth son, reconfirmed and expanded the Karaite charter of Trakai in December 1492, but then in 1495, he expelled all Lithuanian Jews, including the Karaites of Trakai and Volhynia, with everything confiscated being given to the throne, the church, or the Jews' neighbours. ${ }^{55}$ It

52 Bałaban 1927, 59.

53 Szyszman 1935-1936, 48.

54 Szyszman 1935-1936, 49.

55 Bershadsky mentions some Lithuanian Metrica documents that relate to the expulsion of Jews from Lithuania. A document from 8 June 1495 indicates that Alexander the Great gave a 
was only following the death of John Albert ${ }^{56}$ that the Lithuanian Jews were permitted to return to Lithuania. Like his father, Alexander became king of Lithuania and Poland. In 1503, Alexander annulled his own expulsion decree. There is no evidence that Jews returned as a result, but this probably stabilized the situation, and in 1507, Sigismund I reconfirmed the Karaite charter of Trakai, extending some rights in the process. ${ }^{57}$

In conclusion, the medieval settlement of Karaites in Trakai before the expulsion could be characterized by the maintenance of stability. In the extant documents we do not find any complaints about heavy fiscal burdens. Meanwhile, the first sources draw attention to the issue of the Hebrew legacy and great piety of Karaites. The fact that they were written in Hebrew only raises the status of this language within the Karaite community. It proves that Hebrew was not only cultivated for religious reasons in solemn and dignified worship, but that it was the language of daily correspondence. Therefore, the elders were required to be fluent in Hebrew in order to keep contacts with the Karaite co-believers of Constantinople. The Karaite piety reflected in the letters to and from Elijah Bashyatzi refers to Karaite consultation towards some Rabbanite adaptations.

The following centuries brought some changes in Karaite life, and subsequently had a great impact on the attitude of authorities towards Karaites, as well as on relations between Rabbanites and Karaites. The strained relations could be indirectly echoed in the history of the first Karaite settlement in Lithuania passed down orally from generation to generation, as even until the twentieth century Karaites boasted having received Vytautas' charter of privilege in 1388, which in fact has been discredited in recent times. However, this history has become so ingrained in past thinking of all Karaites honouring the famous dukes that it overshadows the true facts of the arrival of Karaites who have become almost forever linked with something they never did. As there was no way of verifying its accuracy, details and meanings changed over time, consequently prevented prejudice and hatred from spreading, protected against religious intolerance and persecution, and helped them to avoid paying certain discriminatory taxes and tolls - in contrast to these difficulties experienced specifically by Rabbanite Jews. The more privileges Karaites obtained from local authorities, the wider the gap that formed in relations between these two

farm in Trakai that had belonged to a Jew named Shlomo, with its livestock, corn, and other property, to his furrier Sova. See Bershadsky 1883, 253.

56 John I Albert (1459-1501; r. 1492-1501) was Casimir's third son. After his death, his brother Alexander was elected king of Poland.

57 Mann 1935, 563. 
groups, and consequently they drifted apart. The history proves that it was an individual and general duty of self-preservation to defend not only the property they possessed, but even their own lives. Karaites identified with this version of history so strongly that not only did they convince the monarchs, but they personally believed it to be the unquestionable truth for many centuries. As a final point, it is fair to say that the authors discussed here did not consider all of the available documents on the origin of the Karaites in Grand Duchy of Lithuania in the fifteenth century, and as a result, their opinions should be viewed with scepticism.

\section{Bibliography}

Bałaban, Majer. Studja historyczne. Warszawa: Księg. i Wydaw. M. J. Freid i S-ka, 1927. Bershadsky 1883 = Бершадский, Сергей Александрович. Литовские евреи. История их юридического и общественного положения в Литве от Витовта до Люблинской унии. 1388-1569 г. Санкт-Петербург: Тип. М. М. Стасюлевича, 1883.

Gąsiorowski, Stefan. Karaimi w Koronie i na Litwie w XV-XVIII wieku. Kraków: Austeria, 2008. Kizilov, Mikhail. "The Arrival of the Karaites (Karaims) to Poland and Lithuania: A Survey of Sources and Critical Analysis of Existing Theories." Archivum Eurasie Medii Aevi 12 (2003-2004): 29-45.

Mann, Jakob. Texts and Studies in Jewish History and Literature. Vol. 2. Karaitica. Philadelphia: Hebrew Press of the Jewish Publication Society of America, 1935.

Schur, Nathan. The Karaite Encyclopedia. Frankfurt am Main: Peter Lang, 1995.

Sinani 1890 = Синани, Исаак. История возникновения и развития караимизма, часть II. Санкт-Петербург: Типография Дома Призрения Малолетних Бедных, Лиговка, д. № $26,1890$.

Smoliński, Józef. “Jeszcze w sprawie Karaimów (Odpowiedź p. Poznańskiemu).” Ziemia 22 (1912): 353.

Sultansky, Mordecai. Sefer Zecher Tzadiqim (ספר זכר צדיקים). Warszawa: Ha-Tzfirah, 1920. Szyszman, Abraham. "Osadnictwo karaimskie i tatarskie na ziemiach Wielkiego Księstwa Litewskiego.” Myśl Karaimska 10 (1933-1934): 29-36.

Szyszman, Abraham. "Osadnictwo karaimskie w Trokach za wielkich książąt litewskich." Myśl Karaimska 11 (1935-1936): 40-68.

Witkowski, Rafat. "Some Remarks on the History of the Karaites in Grand Duchy of Lithuania in the $15^{\text {th }}$ Century." Karaite Archives 1 (2013): 211-241. 
